\title{
An analysis and comparison of two German thrust-fencing manuscripts
}

\author{
Reinier van Noort \\ (Fekteklubben Frie Duellister / Ense et Mente) \\ Jan Schäfer (Schwertspiel e.V.)
}

\begin{abstract}
In this contribution, we will discuss two German fencing manuscripts Mscr.Dresd.C.13 (SLUB Dresden) and Add MS 17533 (BL London). Both manuscripts present texts on thrust-fencing based on the teachings of Salvator Fabris. The dedication of manuscript $\mathrm{C} 13$ was signed by the famous fencing author Johann Georg Pascha. The author of one of the texts contained in the 17533 manuscript is named H.A.V..

A textual analysis has been performed on these two books, and then the contents of the works have been compared. This comparison shows that $\mathrm{C} 13$ presents a largely identical text to the main treatises contained in 17533, the most significant difference being certain additions in C13, which Pascha also discusses in his dedication. Based on our analysis, both $\mathrm{C} 13$ and 17533 appear to present copies of an original text. We further hypothesize that H.A.V., the author of this original text, was Heinrich von und zum Velde, the fencing master of Johann Joachim Hynitzsch.
\end{abstract}

Keywords: Pascha, Fabris, Rapier, German, Fencing treatises

\section{INTRODUCTION}

Salvator Fabris was the fencing master at the Danish court from 1601 until 1606. In that time, he published his treatise on fencing, Lo Schermo, overo Scienza d'Arme, in Copenhagen in $1606 .{ }^{1}$ After publishing this work, Fabris returned to the city of Padua, Italy, where he originally came from. There, he ran his own fencing school until his death in $1618 .^{2}$

However, Fabris's legacy did not end with his death, as he remained acknowledged as one of the greatest fencing masters to have ever lived. His fame was especially large in Germany, where various fencing lineages arose that claimed their origins in the teachings of Fabris, sometimes together with other Italian masters. ${ }^{3}$ These lineages even displaced the original German fencing tradition. Perhaps the most important of these new lineages

\footnotetext{
${ }^{1}$ Fabris, Lo Schermo.

${ }^{2}$ Leoni, Art of dueling, p. xix. See also Sørensen, "A look behind the scenes: Danish Renaissance Martial Arts during the Reign of Christian IV".

${ }^{3}$ Cf. Schöffer von Dietz, Beschreibung der Fechtkunst; Heussler, Neu Kunstlich Fechtbuch; and Hynitzsch, Scienza e pratica d'arme.
} 
was that founded in Jena by the Kreussler family. Unfortunately, no written works produced by this lineage are known until Kahn published his Anfangsgründe der Fechtkunst in 1739.4 Another testimony to the fame and infamy of Fabris and his students is the inclusion of a full chapter titled Contre les postures de Salvator Fabri in Thibault's Academie de l'Espée. ${ }^{5}$

Considering the importance of Fabris's lineage in German fencing from the 1600's onwards, it is of great interest to investigate the earlier developments of this style as it rose to its position of dominance. However, the number of original treatises written in this period by direct students of Fabris is very limited. Hynitzsch argues that whereas Schöffer von Dietz had learned at Fabris's school, he had not been taught by Fabris himself. Heussler was in turn a student of Schöffer. Köppe ${ }^{6}$ offers an interesting insight, outlining differences between the old and new manners of fencing, but was himself not a fencing master, and while he mentions having met Fabris in Paris in 1609, he was not actually a student of Fabris. Other German students of Fabris mentioned by Hynitzsch, such as Hans Wulff von Mulßheim and the members of the Kreussler family, ${ }^{7}$ did not author any treatises known today.

In 1671, Johann Georg Pascha presented a manuscript, Mscr.Dresd.C.13, now held by the Sächsische Landesbibliothek - Staats- und Universitätsbibliothek (SLUB) Dresden, in which he presents thrust-fencing "after the art and manner of Sig. Salvatore", i.e. Salvator Fabris. In this article, the contents of this manuscript will be discussed and compared to another manuscript, Add MS 17533 held by the British Library in London. Furthermore, it will be argued that both these manuscripts present copies (or adapted copies) of an earlier manuscript written by Heinrich von und zum Velde, a direct student of Fabris, and the master of Hynitzsch.

\section{ABOUT JOHANN GEORG PASCHA}

The author of manuscript C13, Johann Georg Pascha, was born in Dresden on 9 September 1628, to Johann Pascha, a servant at the court of the elector-prince of Saxony, and Magdalena Frauenstein. In his youth, he went to school in Zittau and Berlin and then finished his gymnasium in Stettin. After that, most likely before $1645,{ }^{8}$ he became a dancing tutor for the children of the Irish colonel Hamilton (Obrist Hammeldon), and in this position he travelled to Gdańsk and then Greifswald, from which Pascha journeyed on to Rostock. In Greifswald and Rostock, Pascha continued his studies, and it was there

\footnotetext{
${ }^{4}$ Kahn, Anfangsgründe der Fechtkeunst.

5 "Against the postures of Salvator Fabris" - Chapter 33 in: Thibault, Academie de l'Espée. For an English translation, see Greer, Academy of the Sword.

${ }^{6}$ Köppe, Newer Discurs.

7 See Leoni, Art of dueling, pp. xxxii.

8 Dupuis, "The French staff material".
} 
that he learned fencing as well as various other physical exercises. In 1649, Pascha returned home, but already in 1650 he travelled to Wittenberg to once more continue his studies. It was in Wittenberg that Pascha started teaching both physical and rhetorical exercises. In 1656, Pascha was appointed to a position as archivist by Augustus, the Administrator of the Archbishopric of Magdeburg and, from 1657, Duke of SaxeWeissenfels. Some time later, ${ }^{9}$ Pascha also received a position as secretary to the Chancellor of Thuringia. In 1662, finally, Pascha was appointed as Pagen-Hofmeister for the pages of Duke Augustus, in Halle (an der Saale). In the dedication preceding the Eigentliche Beschreibung des Stoßfechtens in einfachen Rappir Pascha refers to these latter two positions. ${ }^{10}$

From 1657 Pascha published and re-published numerous treatises on a wide range of subjects, including both thrust-fencing and cut-fencing, wrestling, drilling with the Jägerstock and with the partisan, vaulting, and flag waving. In these successive treatises Pascha often re-used his older material, but also expanded upon this. In 1671, Pascha presented the manuscript now known as C13. In this work, as he writes in his dedication to Duke Augustus, Pascha presents a style of fencing that was new for him, based on the teaching of Salvator Fabris as passed on by Heinrich von und zum Velde, ${ }^{11}$ which Pascha learned of through a friend who in turn studied under this Heinrich von und zum Velde.

Pascha died on 1 September 1678 after having had a fever since July 19. His death may have been due to a stroke (though by Dupuis theorises Pascha may have died of a contagious disease $\left.{ }^{12}\right)$.

\section{MSCR.DRESD.C.13}

The manuscript Mscr.Dresd.C.13 was written in the name of Johann Georg Pascha, and is dated to $1671 .{ }^{13}$ It contains 214 folios, $30.8 \times 21 \mathrm{~cm}$ in size, with writing in a neat baroque cursive hand on both sides. Comparing the handwriting in the valediction and signature under the manuscript's dedication to the much neater handwriting of the rest of the manuscript strongly suggests that at least two scribes were involved. The

\footnotetext{
${ }_{9}$ Based on Pascha's dedication of the C13 manuscript, this appointment should have occurred in 1666.

10 The above biographic information mainly comes from a sermon written and published for Pascha's funeral: Schradern, Woblanständige Exercitia ... Herrn Johann Georg Paschen, and was also discussed in Dupuis, "The French staff material". For more information, the reader is referred to this work, and the literature discussed by the author.

11 Various forms of his name are found in different sources; Pascha uses Zu dem Felde. Here, we will use Heinrich von und zum Velde, which is how his name was given by his student, Johann Joachim Hynitzsch.

12 Dupuis, "The French staff material".

13 The dedication is dated 26 June 1671 , fol. $4 \mathrm{v}$.
} 
valediction and signature were likely written by Pascha himself, while the rest of the manuscript was penned by one or more professional scribes. The manuscript was acquired by the Kurfürstliche Bibliothek Sachsen (now part of the SLUB) in 1768, when the library purchased the collection of the deceased politician and art collector Heinrich Brühl. The contents of the book can be divided as follows:
$2 \mathrm{r}-110 \mathrm{v}$
Eigentliche Beschreibung des Stoßfechtens in einfachen Rappir kürtzlichen Aus dem berühmten Sig: Salvatore, und andern Vornebmen FechtMeistern zusammen
$111 \mathrm{r}-171 \mathrm{v}$ getragen, und in eine richtige Ordnung gebracbt.
$172 \mathrm{r}-210 \mathrm{v}$ Fecht Lectiones
$211 \mathrm{r}-212 \mathrm{v}$
Folget das Caminiren mit der Resolution des sig. Salvators und sig. Moman. Des Tijboths Fecht=Circul und deßelben bald folgende erklehrung.

Note that in the section on Caminiren mit der Resolution (proceeding with resolution), while the chapter numbers restart at 1 , the numbering of the lessons continues from the preceding section.

The first part of $\mathrm{C} 13$ is the main treatise, containing a technical discussion on fencing with the single rapier based on the teachings of Sig. Salvatore, i.e. Salvator Fabris. Then, the second part consists of 428 numbered lessons, in which the principles explained in the first part are applied. The third part describes proceeding with resolution, an alternative tactical fencing mode, in which, rather than taking a guard and using stepping footwork to approach the opponent, one approaches out of guard, walking continuously with normal paces. Finally, the fourth part contains a very short discussion of the manner of fencing taught by Gerard Thibault. ${ }^{14}$

The text of $\mathrm{C} 13$ contains numerous references to figures, but unfortunately, except for an incomplete and flawed copy of Thibault's circle (on fol. 211r), no figures are included in the book. In addition to Pascha, who claims authorship, C13 mentions the following fencing masters: Sig. Salvatore (2r), Zu dem Felde (4r), Sig. Herman (14r), Tijbott (78v), and Sig. Moman (172r).

\section{ADD MS 17533}

The British Library holds a manuscript with signature BL MS 17533, which is of particular interest here. It was purchased by the Library from A. Asher on 11 November 1848, and in the British Library catalogue is dated to the 18 th century ${ }^{15}$. However, the contents of the manuscript are likely older than that, dating to before roughly the middle of the 17 th

\footnotetext{
14 Thibault, Academie de l'Espée.

15 While the manuscript is dated to the $18^{\text {th }}$ century in the catalogue of the British Library, this date was first given in the BL catalogue of 1868 and has not been verified since. Castle dates this manuscript to the middle of the $17^{\text {th }}$ century; see Castle, Schools and masters of fence, $\mathrm{p}$. XXXIV.
} 
century. The manuscript must either represent a later copy of one or, likely, several 17 th century manuscripts, or the dating given by the BL is incorrect. The name of its author, or at least the author of part of the work, is only given as H.A.V. (on fol. 57r). The manuscript contains 127 folios of approximately 31.5 x $20 \mathrm{~cm}$, both sides of which contain either German writing in a cursive hand or illustrations. The contents of the book can be divided as follows:

\begin{tabular}{|c|c|}
\hline $1 \mathrm{r}-23 \mathrm{v}$ & Fecht Stücke des Sieg: Salvators \\
\hline $24 r-38 v$ & Folget daß Caminiren mit der Resolution des Sig. Salvators und Sig. Moman \\
\hline $38 v-39 v$ & Des Tijboths Fecht=Circul undt desselben Erklärung. \\
\hline $40 r-56 r$ & 93 drawings in Indian ink \\
\hline $57 \mathrm{r}-101 \mathrm{v}$ & $\begin{array}{l}\text { Gross und kleiner Tractat, und eigentliche beschreibung des Stoß Fechtens in } \\
\text { einfachen Rappir kürtzlichen auß dem Fundament zusammen getragen, wie folget: } \\
\text { Die Fundamenta des Fechtens in einfachen Rappier auß Mund und schrifftlichen } \\
\text { Information des Sig: Salvators und andern vornehmer Fechtmeister in Italia } \\
\text { zusammen getragen undt in eine richtige Ordnung gebracht durch H. A. V. }\end{array}$ \\
\hline $101 \mathrm{v}-117 \mathrm{r}$ & $\begin{array}{l}\text { Fechtkunst in Einfachen Rappier. Kürtzlich in gewiße Praecepta und Ordnung } \\
\text { verfaßet }\end{array}$ \\
\hline $117 r-118 r$ & $\begin{array}{l}\text { Folget waß derjenige zum Vortheil hat, welcher wieder seinen Adversarium der } \\
\text { sich gelagert hat, mit der Resolution gehet. }\end{array}$ \\
\hline $118 \mathrm{r}-118 \mathrm{v}$ & Des Tÿbauts Fecht Circul undt Erklärung darüber. \\
\hline $118 \mathrm{v}$ & Eine verführliche Stoccate wieder einen Tolch, so mißlich zu Pariren ist \\
\hline $118 \mathrm{v}-$ & Daß Hieb Fechten \\
\hline
\end{tabular}

The first part consists of 132 numbered lessons on fencing with the single rapier. The second part describes the proceeding with resolution. The third part is a very short discussion on the manner of fencing taught by Thibault (with an incomplete and incorrect copy of Thibault's circle on 39v). The fourth part contains 93 artful, simple drawings in Indian ink. The first illustration (La Natura de Tagli) shows a naked man around whom the directions of the cuts are indicated, with their Italian names. This is comparable to the illustrations in Fabris's Lo Schermo ${ }^{16}$ and Hynitzsch's Scienza e pratica d'arme, ${ }^{17}$ except that the diagonal cuts are shown on more horizontal lines, and the mandritto squalembrato is misnamed riverso squalenbrato. The remaining 91 illustrations (three illustrations per page, placed above each other) show pairs of fencers (dressed) executing fencing techniques. The numbering of the illustrations jumps from 51 to 53, skipping 52. It is unknown whether this is only a numbering error, or if illustration 52 was never added to the set. The fifth part is a technical treatise on (thrust-)fencing with the single rapier based on the teachings of Sig. Salvator and other distinguished fencing masters in Italy. Interestingly, the author or compiler of this treatise, H.A.V., claims to have compiled this from oral

\footnotetext{
16 Fabris, Lo Schermo (transl. Leoni), p. 27.

17 Hynitzsch, Scienza e pratica d'arme, p. 62.
} 
and written information received from these masters, suggesting that H.A.V. was a direct student of Fabris. The sixth part presents an abridged copy of this fifth part, largely corresponding in content, but leaving out the Chapters 15, 16, 17 and 19, and placing Chapter 20 in front of Chapter 18. The seventh part repeats the final two chapters of the second part (on proceeding with resolution), in inverted order and with minor changes to the text. The eighth part repeats the discussion of Thibault's circle (with minor corrections in its references to the letters on the circle, though the circle is not drawn here). The manuscript then contains a single lesson against a dagger (presumably used as an off-hand weapon next to the rapier), devised by an unnamed Roman master, and passed on by a $S$. Westphall. Finally, the tenth part of the manuscript contains a treatise on cut-fencing ${ }^{18}$ which has the same outline as the treatise published by Erhardus Henning in 1658, ${ }^{19}$ except that in 17533 Chapter 13 is included in Chapter 12. There are, however, further differences, as 17533 presents a significantly expanded version of the text, containing a larger number of lessons along with some other minor changes in the content. The text of 17533 refers to the following fencing masters: Sig. Salvator (1r), Sig. Moman (24r), Tijboth (38v), H.A.V. (57r), Sig. Herman (61r).

\section{COMPARISON OF 17533 AND C13}

What makes Add MS 17533 particularly interesting is that the texts it contains are largely identical to the texts in Mscr.Dresd.C.13. The first part of 17533 largely corresponds with the second part of $\mathrm{C} 13$, though where the individual lessons in 17533 often contain multiple alternatives, in $\mathrm{C} 13$ these alternatives are generally split apart into separate lessons. Furthermore, C13 contains additional lessons, in particular in Chapter 11, the title and contents of which Pascha changed to include parries and holds. In turn, C13 leaves out the last four lessons (129-132) of Chapter 32, on the mixed use of cuts and thrusts (erroneously numbered Chapter 33 in 17533). Also note that in 17533 the title of this part mentions Sig. Salvator as the originator of the lessons, whereas this reference is left out in C13.

The second part of 17533 in turn agrees with the third part in C13, with only minor omissions. Again, the lessons of 17533 are split up into multiple lessons in C13. The only notable difference is the omission in C13 of no. 45 in Chapter 9.

The discussions of Thibault's circle and manner of fencing given in the two manuscripts closely resemble one another. Relative to the C13, the first version of this text in 17533 contains one minor omission (likely a scribal error), which is included in 17533 in the repetition. Interestingly, both the $\mathrm{C} 13$ and the first 17533 refer to position $e$ on the circle where $c$ is meant, but this is corrected in the second instance in 17533. In both manuscripts, the circle is incomplete, missing various lines, and drawn somewhat

\footnotetext{
18 Hieb-fecbten

${ }^{19}$ Henning, Unterricbtung vom Hieb-fechten.
} 
incorrectly, with the lines coming from the four corners of the square not passing through the centres of the sides opposite these corners, as they should. In the 17533 drawing, the offsets are larger than in the C13 manuscript. When comparing the two circles to the circle shown in an engraving of a fencing school in Leiden, ${ }^{20}$ this engraving contains all lines given in the manuscripts, and adds the orthogonal and diagonal lines crossing in the centre of the circle, but is still missing various other sets of lines relative to the circle given by Thibault himself. Note that in the engraving the diagonal lines from the corners of the square also do not all meet properly in the centres of the opposite sides of the square, possibly due to issues stemming from drawing the circle in perspective.

Finally, the treatise given in the fifth part of 17533 corresponds to the treatise given in the first part of C13. The main differences are that in C13 Chapter 5 is expanded to include discussions on parries and holds, and in C13 the final paragraph from Chapter 17 is missing. In addition, there are some minor differences in paragraph numbering, and in 17533 Chapters 18 and 19 are interchanged (a note under the title of Chapter 18 in 17533 indicates they should be switched, see fol. 94r).

The figures contained in 17533 belong to both the technical treatise (fifth part) the lessons (first part) and the proceeding (second part), though in the lessons and proceeding, figure references are kept blank, the numbers to be filled in later. In C13, these numbers are given, though. The sixth part of 17533 contains some references to the figures, though they are not as common as in the fifth part.

Pascha writes in his dedication that he presents the fencing lessons of Von und zum Velde, but has added his own lessons about das pariren [...], wie auch die prisen, und andere lectiones und lager (parrying, as well as holds, and other lessons and guards) between these lessons, as Pascha felt these things were missing. Indeed, in the technical treatise (C13 part 1), chapter 5 is expanded to discuss not only tempo and contra-tempo, but parries, holds, tempo and contra-tempo. Likewise, in the Lessons (C13 part 2), Chapter 11 is expanded to deal not only with tempo and contra-tempo but also with parries and holds, adding 21 additional lessons to this chapter alone (not counting the increase in the number of lessons from dividing the single paragraph in 17533 into 25 individual lessons in C13). Based on the great similarities between the two texts shown in our comparison, it thus seems likely that Pascha had access to a copy of the same texts as presented in parts 1,2, 3 and 5 of 17533 . However, it is unlikely that Pascha had access to 17533 itself, as the text in 17533 is incomplete, missing, for example, its lesson 54 (in the Lessons section), which is included in C13 as lessons 191-193, and lacking many figure references that are filled in in C13. Furthermore, the relatively sloppy layout and execution of 17533 compared to C13, with new treatise parts starting in the middle of a page, for example, and the repetitions of certain sections with corrections suggest that 17533 is a (later) copy of one

20 Schermschool van de Universiteit van Leiden, engraving by Willem Isaacsz. van Swanenburg, 1610. See for example object number RP-P-1894-A-18591 in the collection of the Rijksmuseum in Amsterdam: https://www.rijksmuseum.nl/nl/collectie/RP-P-1894-A-18591 
or more books, sharing a source (authored by H.A.V.) with the text presented and expanded upon by Pascha in his C13.

\section{THE IDENTITY OF H.A.V.}

Unfortunately, it is not possible to determine the identity of the author, and, presumably, fencing master, H.A.V. with complete certainty. However, it is possible, and certainly interesting, to speculate. In the introduction to his 1677 German translation of Fabris, ${ }^{21}$ Johann Joachim Hynitzsch mentions a certain Sig. Herman, who was a German and had been a student of Fabris. It is to this Sig. Herman that Fabris, on his deathbed, bequeathed his salle and students in Padua. However, Sig. Herman was murdered a few months later by his provost, another German named Heinrich. Both Herman and Heinrich could be considered as candidates for the identity of the mysterious H.A.V., as they would both have received oral instruction from Salvator Fabris. However, seeing that Herman was murdered by Heinrich so soon after Fabris's death, he likely did not have time to prepare such a treatise. After murdering Herman, Heinrich fled Padua, and Hynitzsch further reports that he heard from various Cavaliers that they had, in their youth, received instruction in a style of fencing comparable to that of Fabris from a certain Heinrich. This Heinrich would, therefore, have had the opportunity to prepare MS 17533, and it cannot be excluded that he was its author.

In addition to Sig. Herman and Heinrich, however, Hynitzsch also discusses his own fencing master, Herr Heinrich von und zum Velde (1585-1662), who, Hynitzsch says, never failed to praise and quote Fabris and Herman in both his written and oral instruction. Furthermore, it is thanks to this particular Heinrich, Hynitzsch tells us, that Fabris's instruction survived in a pure form in Germany at the time of writing. Heinrich von und zum Velde thus knew Sig. Herman, and, as stated by Pascha in C13, also studied under Fabris. (Considering Herman's untimely demise soon after Fabris died, this is indeed likely.) Furthermore, following Hynitzsch, there must have been written teachings by Heinrich von und zum Velde. Such writings would include references to both Sig. Fabris and Sig. Herman. Indeed, Add MS 17533 frequently refers to Sig. Salv. (and Sig. Salvator is also given as originator of much of the contents of the book), or Sig. Herman (fol. 61r), the latter abbreviated to S. H. after its first occurrence, and C13 copies these references (e.g., see fol. $14 \mathrm{r}$ and $47 \mathrm{v}$ ). The text in manuscript 17533 therefore conforms to the description given by Hynitzsch of writings by Heinrich von und zum Velde. Furthermore, the author of 17533 claims to have received oral instruction from Fabris, which Heinrich von und zum Velde likely had. In turn, Pascha writes that in C13 he presents the lessons of Von und zum Velde, adding his own lessons on parrying and holds, and indeed C13 closely follows 17533 and adds such lessons. Therefore, it seems very likely indeed that the mysterious H.A.V. who authored BL MS 17533 is Heinrich

${ }^{21}$ Hynitzsch, Scienza e pratica d'arme. For an English translation of this foreword, see: Leoni, Art of dueling. 
von und zum Velde. Unless a hitherto unknown manuscript is found which is unmistakably authored by Heinrich von und zum Velde, this assertion cannot be proven. Furthermore, this assertion leaves open the question of the initial A. in H.A.V..22

The noble Zum Velde family came from Hamburg to Stralsund, on the coast of Pomerania, in the 16th century, before 1546 when the first Jürgen zum Velde became councillor in Stralsund. ${ }^{23}$ Jürgen zum Velde had a son, also named Jürgen zum Velde, who was also a councillor in Stralsund, from 1602, and Heinrich von und zum Velde was in turn born as the second son of this Jürgen zum Velde and Anna Gottschalk (Heinrich's older brother was, perhaps predictably, named Jürgen). Heinrich was likely born around 28 May 1585, on the island of Rügen, off the coast of Pomerania, where his family owned some land. ${ }^{24}$

While we do not know much about Heinrich's youth and education, in 1621 he first arrives at the Stift (collegiate church) of St. Petri et Pauli in Magdeburg, where he would work as a Canon for most of his life. ${ }^{25}$ Later, in 1637 it is reported that Heinrich returned to the Stift, suggesting that he left for some time, possibly to escape the sack of Protestant Magdeburg by Catholic forces on 20 May 1631 (after a siege which started in November 1630). ${ }^{26}$ As Von und zum Velde worked as a Canon for 31 years, ${ }^{27}$ this suggests that he may have left Magdeburg around 1627. Alternatively, then, his departure may have been related to the siege of Stralsund (May to August 1628), or the death of his older brother (who fell ill while representing Stralsund at a gathering of the Hanseatic League in Lübeck. ${ }^{28}$ ) Heinrich von und zum Velde likely worked at the Stift from 1637 until his death in 1662, teaching fencing at the school or privately. As Heinrich von und zum Velde died in Leipzig in 1662, if he is indeed the author of the original treatise on which 17533

22 Potentially, this A. stands for "Aus" (Heinrich Aus Velde), or Latin "Ad” (Heinrich Ad Velde). Alternatively, it could be a copying error which must then have taken place in the production of an earlier copy on which both 17533 and C13 are eventually based.

23 See Stadtarchiv der Hansestadt Stralsund. HS 365. XXXXVII. Nachrichten die Rathspersonen der Stadt Stralsund betreffend. Stammtafeln und Wappen derjenigen Familien deren Angehörige die Bürgermeiste oder Ratswürde der Stadt bekleidet haben. Zweiter Teil, fol. 115a-116. (http://ub-goobi-pr2.ub.unigreifswald.de/viewer/fullscreen/PPNArchivHSTChronik0027/203/), and: Zdrenka, Die Inschriften des Landkreises Rügen, pp. 153-154.

24 As indicated on Heinrich's portrait in Hynitzsch, Scienza e pratica d'arme, he was 77 years minus 6 weeks old when he died on April 16, 1662.

25 "H. Heinrich von Velde ins Stiffte gekommen [...]". See: Historia des Collegiat-Stiffts St. Petri et Pauli in der Neustadt Magdeburg aus etlichen Annalibus, Privilegiis etc. von des Stiffts Fundation an bis auf gegenwärtige Zeiten, s. d." Sig.: A 4d, Stift St. Petri und Pauli in der Neustadt Magdeburg (1344-1816) Da Nr. 27a, Landesarchiv Sachsen-Anhalt.

26 Anno 1637 H. Heinrich von Velde wieder bei dem Stiffte gekommen. in ibidem.

27 According to his portrait in Hynitzsch's Scienza e pratica d'arme.

28 See: Zober, Geschichte der Belagerung Stralsund's, pp. 106-107. 
and $\mathrm{C} 13$ are based, this would place the production of that treatise to at least before that year. The next question to be answered, then, is who was Pascha's good friend from whom he received Von und zum Velde's lessons.

\section{PASCHA AND HYNITZSCH}

In 1673, Christina Hauptmann from Dresden married Johann Joachim Hynitzsch (1638$1707)^{29}$, master of exercise in Leipzig as her second husband. Later, in 1687, Christina's fourth daughter from her first marriage, Johanna Gertraud, married Johann Pascha (Dresden 1653 - Leipzig 1710), a master of exercise in Leipzig. ${ }^{30}$ It is very tempting to use this connection to argue that contact between the families may have existed before, and that Johann Georg Pascha and Johann Joachim Hynitzsch may have known each other, but it is not even certain if the mentioned Johann Pascha was related to Johann Georg Pascha. However, considering the relatively short distance between the two neighbouring cities Halle (where Pascha was active) and Leipzig (where Hynitzsch was active), and considering that Pascha and Hynitzsch were both teaching fencing and similar activities, it is not unlikely that Johann Georg Pascha and Johann Joachim Hynitzsch would have known each other, or at least would have met. In the dedication of C13, Pascha writes that he had learned of the art and manner of thrust-fencing of Salvator (Fabris) through a friend, who learned it from the noble Von und zum Velde, who in turn learned this from Fabris himself. Based on the above, it is therefore not at all unlikely that this friend was Johann Joachim Hynitzsch, who we know was a student of the noble fencing master Heinrich von und zum Velde. ${ }^{31}$ Pascha may thus have learned fencing according to the art and manner of Fabris or, more likely, have received (a copy of) the treatise written by Heinrich von und zum Velde, which is now preserved in the British Library in Add MS 17533, from Johann Joachim Hynitzsch. Pascha subsequently copied and amended this text to his own insights to produce the text presented in C13.

\section{FENCING MASTERS NAMED IN 17533 AND C13}

Of the various fencing masters named or referred to in 17533 and C13, we have already identified Salvator Fabris, Gerard Thibault, Heinrich von und zum Velde, and Sig. Herman, and we have hypothesized on the identity of H.A.V.. Additionally, both books mention a Sig. Moman, as one of the originators, together with Sig. Salvator, of the Caminiren mit der Resolution, or proceeding with resolution. Unfortunately, this fencing master is not known elsewhere and has left no other writings or signs. Hence, the identity

\footnotetext{
29 See: Breul, Bey der Woblansehnlichen ... Herren Joh. Joachimus Hynitzsch. This also indicates that later in his life, Hynitzsch spent significant time in Halle.

30 Petermann, Pasch, Beschreibung wahrer Tan₹-Kunst.

31 Hynitzsch, Scienza e pratica d'arme.
} 
of this Sig. Moman is still a mystery to us..$^{32}$ Finally, 17533 contains one lesson discussing how to attack against an opponent armed with (a rapier and) a dagger. According to the author, this lesson was devised by a Roman master, whose name is not given, and communicated by a S. Westphall, who, until now, has not been further identified by us.

\section{CONCLUSION}

We have analysed and compared the contents of two German fencing manuscripts. This analysis has shown that Add MS 17533 (BL) and Mscr.Dresd.C.13 (SLUB) contain similar treatises dealing with thrust-fencing in the tradition of Fabris. Furthermore, we have argued that the original text of which both manuscripts likely present copies was written by Heinrich von und zum Velde, who was a direct student of Fabris and the fencing master of Johann Joachim Hynitzsch.

One of the manuscripts, C13, was signed by (and likely produced for) Johann Georg Pascha in 1671. As noted by Pascha in his dedication, Pascha made some additions and changes to the original text, which he had received from a friend. The shared contents of C13 and 17533 give a very interesting insight into the early development of the Fabrisian fencing tradition in Germany, as taught by Fabris's own students. Furthermore, the additions and omissions made by Pascha in turn show how the tradition started to develop half a century after Fabris's death, amongst his students' students, showing an increased focus on parrying, and perhaps reducing the mixed use of cuts and thrusts.

\section{BIBLIOGRAPHY}

\section{Primary sources}

Otto Friedrich Breul, Bey der Wohlansehnlichen Leichbegängnüs des Wohl-Edlen Hochachbahren und Wohl-Mannvesten Herren Joh. Joachimus Hynitzsch (Halberstadt: Johann Erasmus Hynitzsch, 1707)

Salvator Fabris, Lo Schermo, overo Scienza d'Arme (Copenhagen: Henrico Waltkirch, 1606)

Erhardus Henning, Kurtze jedoch gründliche Unterrichtung vom Hieb-fechten (Königsberg, 1658)

Sebastian Heussler, Neu Kunstlich Fechtbuch (Nürnberg: Ludwig Lochner, 1615)

Johann Joachim Hynitzsch, Scienza e pratica d'arme = Herrn Salvatore Fabris Obristen des Ritter-Ordens der sieben Hertzen verteutschte Italiänsche FechtKunst (Leipzig: Erasmus Hynitzsch, 1677)

\footnotetext{
32 "Moman" could potentially be the result of another copying error, in which case Sig. Herman may have been intended.
} 
Anton Friedrich Kahn, Anfangsgründe der Fechtkunst (Göttingen: Johann Christoph Ludolph Schultzen, 1739)

Joachim Köppe, Newer Discurs von der Rittermeßigen und Weitberümbten Künst des fechtens (Magdeburg: Andreas Betzeln, 1619)

Hans Wilhelm Schöffer von Dietz, Gründtliche und eigentlichte Beschreibung der Fechtkunst (Marburg: Johan Saurn, 1620)

Christoph Schradern, Wohlanständige Exercitia eines Christen / dem weiland edlen / froßachtbaren und wohlgelahrten Herrn Johann Georg Paschen (Halle: Salfeld, 1678)

Girard Thibault, Academie de l’Espée (Leiden: Elsevier, 1630)

\section{Secondary sources}

Castle, Egerton, Schools and masters of fence (London: George Bell, 1885)

Dupuis, Olivier, "The French staff material from Johann Georg Pasch", Acta Periodica Duellatorum 4 (2016), 1, 53-101

Greer, John Michael, Academy of the Sword: The mystery of the Spanish Circle in Swordsmanship and Esoteric Arts (Highland Village: Chivalry Bookshelf, 2006)

Leoni, Tomasso, Art of dueling: Salvator Fabris' rapier fencing treatise of 1606 (Highland Village: Chivalry Bookshelf, 2005)

Petermann, Kurt, Pasch, Beschreibung wahrer Tanz-Kunst. Mit einem Nachwort und einem Register von Kurt Petermann (Leipzig: Zentralantiquariat, 1978)

Sørensen, Claus, "A Look Behind the Scenes: Danish Renaissance Martial Arts during the Reign of Christian IV", Acta Periodica Duellatorum 4 (2016), 2, 31-45

Zdrenka, Joachim, Die Inschriften des Landkreises Rügen (Berlin: Walter de Gruyter, 2002)

Zober, Ernst-Heinrich, Geschichte der Belagerung Stralsund's durch Wallenstein im Jabr 1628 (Stralsund: Trinius, 1828) 